\title{
SURVEY OF SPIDER POPULATIONS (ARANEAE) IN TOMATO FIELDS AT FAYOUM GOVERNORATE
}

\author{
El-Khouly, N. M., Rahil, A. A. and Dwedar, E. F
}

\begin{abstract}
Survey of spiders in tomato plantations was carried out in AlMandara region Fayoum Governorate, from Nov. 2012 till Sep. 2014. Collection of spiders started two weeks after planting and continued weekly to the end of season. Results revealed the existence of 42 species that belong to 34 genera in 14 families. Population densities and seasonal fluctuations in relation to weather conditions were estimated. The most dominant families were Theridiidae, Lycosidae and Dictynidae, represented by $36.02 \%, 21.01 \%$ and $20.62 \%$, respectively. In moderate numbers were families Miturgidae and Philodromidae, represented by $8.01 \%$ and $5.75 \%$, respectively. The rest of families were found in low or rare numbers as follow; Thomisidae $2.4 \%$, Araneidae $2.3 \%$, Salticidae $1.6 \%$, Pisauridae $0.8 \%$, Gnaphosidae $0.6 \%$, Linyphiidae $0.4 \%$, Pholcidae $0.2 \%$, Clubionidae $0.1 \%$ and Mimetidae $0.1 \%$. In general two species Anelosimus aulicus (Theridiidae) and Dictyna segregate (Dictynidae) were most dominant being $32.01 \%$ and $20.62 \%$ of the population of spiders community inhabiting tomato fields.

Statistics indicated insignificant correlation between spider populations and temperature, with negative significant correlation for relative humidity and population during nili plantation 2012/2013, whereas in nili plantation 2013/2014 the positive correlation between populations was only for temperature, with no significant correlation with relative humidity. In summer plantation 2013, a positive significant correlation was found for both temperature and relative humidity, but in summer plantation 2014, high positive correlation was found between population and temperature only, with no significant correlation with relative humidity.
\end{abstract}

Key words: Spiders- Survey- Araneae- Population densities- Population fluctuation.

\section{INTRODUCTION}

Tomato (Lycopersicon esculentum L.) is a main vegetable crop in Egypt that represents $35 \%$ of the total vegetable production (Zaki, 1992). Arthropods comprise the most diverse organisms in any terrestrial environment. However, enough information's on diverse groups, such as spiders (Araneae) are lacking (Longino, 1994). Currently, Spiders, as important predators, are one of the most diverse and abundant groups that prevail under different environments with almost 42.473 species described in Phylum Arthropoda (Platnick, 2011). Due to

Fayoum J. Agric. Res. \& Dev., Vol. 29, No.2, July, 2015 
their presence in large numbers and capabilities to capture the prey, spiders in some crops can be considered as potentially important bio-control agent. For instances, predators surveyed in rice fields in Kafr El-Sheikh, Egypt, included 13 species of orb web spiders (Sherif et al., 2002) of which Argiope spp. captured 33 species of phytophagous insects and the others captured 14 to 21 prey species.. In El- Fayoum Governorate (Rahil, 2006) collected eighteen spider species in six families from tomato fields. Many species belonging to combfooted spiders (Araneae: Theridiidae) described by (Levy and Amitai, 1982) of which the main species was Anelosimus aulicus (Koch). Nevertheless, the present study was designed to reveal some ecological aspects of some field spiders and population fluctuations as related to weather conditions in Fayoum Governorate.

\section{MATERIALS AND METHODS}

\section{Population densities of spiders in tomato fields.}

Al-Mandara region, Fayoum, was chosen where seedling of tomato, Lycopersicom esculentum Mill, Marwa and Basha. Varieties were transplanted during the period from Nov. 2012 to Sept. 2014, in an area of 1/8 feddan and cultivated in two plantations (nili and summer). Sampling started two weeks after planting and continued weekly till the end of each season. All usual agricultural practices were followed, without the use of pesticides. To collect aerial and ground species of spiders, direct count and pitfall traps were used to estimate populations.

For direct count of spiders, fifteen leaves were weekly examined. Spiders collected were immediately preserved in glass vials $\left(15 \mathrm{~mm}^{3}\right)$ containing $70 \%$ ethyl alcohol and 30\% glycerin, identified using a binocular microscope.

For traps, ten pitfall traps were used. The trap was prepared by imbedding a wide-mouth, $1 / 2$ liter glass jar in the soil, so that the top of which was even with soil surface. The fallen spiders were weekly collected and immediately preserved in the preservative for Lab. counting and classification.

Identification of the collected species was carried out according to Denis (1947), Bristowe (1941 and 1958), Kaston B. and Kaston E. (1953), Levy and Amitai (1982) and Breene et al., (1993).

\section{RESULTS AND DISCUSSIONS}

\section{Families and species of spiders collected from tomato plants.}

Survey revealed the existences of 42 species of spiders that belong to 34 genera in 14 families as shown in table (1). The collected spiders could be classified as: a) web-building spiders; Araneidae (5 genera), Theridiidae (4 genera), Linyphiidae (2 genera) Dictynidae and Pholcidae (one genus each), of the $1^{\text {st }}$ group, Genus Argiope and Theridion only included 2 species and b) Hunter spiders; Lycosidae (6 genera), Salticidae (5 genera), Gnaphosidae, Pisauridae, and Thomisidae (2 genera). Clubionidae, Mimetidae, Miturgidae and

Fayoum J. Agric. Res. \& Dev., Vol. 29, No.2, July, 2015 
SURVEY OF SPIDER POPULATIONS (ARANEAE) IN TOMATO 38

Philodromidae, (one genus each), of the $2^{\text {nd }}$ group, genus Allocosa and Pardosa, included 2 species each and genus Lycosa \& Pirata included 3 species each.

Table: (1) Spiders families and species collected from tomato fields at Fayoum Governorate during 2012-2013 and 2013-2014 seasons.

\begin{tabular}{|c|c|c|}
\hline No. & Families & Species \\
\hline 1 & Araneidae Simon & $\begin{array}{l}\text { Araneus nordamanni (Thorell) } \\
\text { A. trifasciata (Forskall,1775) } \\
\text { A. argentata (Fabricius) } \\
\text { Eustala cepina } \text { (Walckenaer) } \\
\text { Metazygia witteldae (Mc Cook) } \\
\text { Zvgiella } x \text {-notata (Clerck,1757) }\end{array}$ \\
\hline 2 & Clubionidae Wagner & Clubiona stagnatilis Kulczynski \\
\hline 3 & Dictynidae Cambridge & Dictyna segregata Gertsch\&Mulaik \\
\hline 4 & Gnaphosidae Pocock & $\begin{array}{l}\text { Drassyllus depressus } \text { (Emerton) } \\
\text { Zelotes subterraneus (C.L. Koch,1833) }\end{array}$ \\
\hline 5 & $\underline{\text { Linyphiidae Blackwall }}$ & $\begin{array}{l}\text { Meioneta fabra Keyserling } \\
\text { Microneta viaria Blackwall }\end{array}$ \\
\hline 6 & Lycosidae Sundeval & $\begin{array}{l}\text { Allocosa funereal } \text { (Hentz) } \\
\text { A. absoluta } \text { Gertsch } \\
\text { Hogna antelucana } \text { (Montgomery) } \\
\text { Lycosa avida Walckenaer } \\
\text { L. carolinensis Walckenaer } \\
\text { L. gulosa Walckenaer } \\
\text { Pardosa distincta } \text { (Blackwell) } \\
\text { P. milvina } \text { (Hentz) } \\
\text { Pirata montanus } \text { Emerton } \\
\text { P. minutes } \text { Emerton } \\
\text { P.piratical } \text { (Clerck) } \\
\text { Schizocosa bilineata } \text { Emerton }\end{array}$ \\
\hline 7 & Mimetidae Simon & Mimetus puritanus Chamberlin \\
\hline 8 & Miturgidae Simon & Chieracanthium jovium (Denis) \\
\hline 9 & Philodromidae Thorell & Thanatus formicinus (Clerck,1757) \\
\hline 10 & Pholcidae C.L. Koch & Pholcus phalangioides Fuesslin, 1755 \\
\hline 11 & Pisauridae Semone & $\begin{array}{l}\text { Dolomedes triton Hentz } \\
\text { Pelopatis undulate( Keyserling) }\end{array}$ \\
\hline 12 & Salticidae Blackwall & $\begin{array}{l}\text { Eris aurantia } \text { (Lucas) } \\
\text { Onondaga lineate Peckham et Peck. } \\
\text { Paraphidippus aurantia (Lucas) } \\
\text { Sassacus cyanea } \text { (Hentz) } \\
\text { Zygoballus bettini } \text { Peckham }\end{array}$ \\
\hline 13 & Theridiidae Sundevall & $\begin{array}{l}\text { Anelosimus aulicus } \text { ( Koch ) } \\
\text { Dipoena nigra } \text { (Emerton) } \\
\text { Theridion murarium } \text { Emerton } \\
\text { T. simile } \text { C. } \text { L. Koch } \\
\text { Parasteatoda tepidariorum } \text { Koch }\end{array}$ \\
\hline 14 & Thomisidae Sundevall & $\begin{array}{l}\text { Misumena vatia (Clerck,1757) } \\
\text { Thomisus onustus (Walckenaer) }\end{array}$ \\
\hline
\end{tabular}

Fayoum J. Agric. Res. \& Dev., Vol. 29, No.2, July, 2015 


\subsection{Population density and relative abundance of spiders collected.}

Nili 2012- 2013: As shown in table (2), 29 species in 25 genera in 10 families were found. The largest numbers belong to Theridiidae (166.0 individuals), Dictynidae (90.0 individuals) and Lycosidae (83.0 individuals), represented 38.52\%, 20.88\% and $19.26 \%$ of the total population, respectively. Miturgids spiders were found in moderate numbers; 31.0 individuals (7.19\%). Philodromids, thomisids and araneids spiders were in low numbers; (23.0, 14.0 and 13.0 individuals), represented $5.34 \%, 3.25 \%$ and $3.02 \%$, respectively. Salticids, pisauridis and linyphiidis spiders only represented $1.16 \%, 0.92 \%$ and $0.46 \%$, respectively.

The numbers of A. aulicus (Theridiidae) 152.0 and D. segregate (Dictynidae) 90.0 , these dominant species, represented $35.27 \%$ and $20.88 \%$, respectively of the spider community in the field. The populations of the lycosid, P. montanus and the miturgid, $C$. jovium were moderate being 36.0 and 31.0 individuals, represented $8.35 \%$ and $7.19 \%$, respectively. Two species; T. formicines (Philodromidae) and L. avida (Lycosidae) were in low population, represented 5.34\% and 3.71\%, respectively. On the other hand, 23 species were rarely found ( $<10$ individuals/season).

Summer 2013:

Results in table (3) revealed that the existence of 24 species in 21 genera in 13 families. The largest numbers belong to Theridiidae (189.0 individuals), Lycosidae (128.0 individuals) and Dictynidae (121.0 individuals), represented $34.17 \%, 23.14 \%$ and $21.88 \%$ of the total population, respectively. Miturgids and philodromids spiders were in moderate numbers; 42.0 and 35.0 individuals, represented $7.59 \%$ and $6.33 \%$, respectively. Eight families were rare as follows; Thomisidae, Araneidae, Salticidae, Gnaphosidae, Clubionidae, Linyphiidae, Pisauridae and Mimetidae, represented 1.63\%, 1.44\%, 1.44\%, 0.90\%, 0.54\%, $0.36 \%, 0.36 \%$ and $0.18 \%$, respectively of the populations.

The numbers of $A$. aulicus (Theridiidae) 171.0, D. segregate (Dictynidae) 121.0 and L. carolinensis (Lycosidae) 65.0 individuals these dominant, represented $30.92 \%, 21.88$ and $11.75 \%$, respectively of the populations. The populations of the miturgid $C$. jovium and the philodromid $T$. formicinus were in moderate being 42.0 and 35.0 individuals, represented $7.59 \%$ and $6.33 \%$, respectively. Three species; P. minutus (Lycosidae), L. avida (Lycosidae) and D. nigra (Theridiidae) were in low population, represented $4.88 \%, 3.62 \%$ and $1.99 \%$, respectively. On the other hand, 16 species were rarely found $(<10$ individuals/season). 
SURVEY OF SPIDER POPULATIONS (ARANEAE) IN TOMATO.

Table: (2) Population density and relative abundance of spider families and species collected from tomato fields during (Nov.2012 to Feb. 2013) in nili plantation in Fayoum Governorate.

\begin{tabular}{|c|c|c|c|c|c|c|}
\hline \multirow{2}{*}{ Families } & \multirow{2}{*}{ Species } & \multicolumn{2}{|c|}{ Collection method } & \multirow[t]{2}{*}{ Season Total } & \multicolumn{2}{|c|}{ Relative abundance \% } \\
\hline & & D. C. & Pf. t. & & (Species) & (Families) \\
\hline \multirow{6}{*}{ Araneidae } & A. trifasciata & 04 & - & 04 & 0.93 & \multirow{6}{*}{3.02} \\
\hline & A. argentata & 01 & - & 01 & 0.23 & \\
\hline & A. nordamanni & 04 & - & 04 & 0.93 & \\
\hline & E. cepina & 02 & - & 02 & 0.46 & \\
\hline & M. wittfeldae & 02 & - & 02 & 0.46 & \\
\hline & Sub total & 13 & - & 13 & & \\
\hline Dictynidae & D. segregate & 87 & 03 & 90 & 20.88 & 20.88 \\
\hline Linyphiidae & M. viaria & - & 02 & 02 & 0.46 & 0.46 \\
\hline \multirow{9}{*}{ Lycosidae } & A. funereal & - & 09 & 09 & 2.09 & \multirow{9}{*}{19.26} \\
\hline & L. avida & - & 16 & 16 & 3.71 & \\
\hline & H.antelucana & - & 04 & 04 & 0.93 & \\
\hline & L. gulosa & - & 02 & 02 & 0.46 & \\
\hline & P. montanus & - & 36 & 36 & 8.35 & \\
\hline & $P$. distinct & - & 08 & 08 & 1.86 & \\
\hline & P. milvina & - & 06 & 06 & 1.39 & \\
\hline & S. bilineata & - & 02 & 02 & 0.46 & \\
\hline & Sub total & - & 83 & 83 & & \\
\hline Miturgidae & C. jovium & 31 & - & 31 & 7.19 & 7.19 \\
\hline Philodromidae & T. formicinus & 02 & 21 & 23 & 5.34 & 5.34 \\
\hline \multirow{3}{*}{ Pisauridae } & P. andulata & - & 02 & 02 & 0.46 & \multirow{3}{*}{0.92} \\
\hline & D. triton & - & 02 & 02 & 0.46 & \\
\hline & Sub total & - & 04 & 04 & & \\
\hline \multirow{4}{*}{ Salticidae } & E. aurantia & - & 02 & 02 & 0.46 & \multirow{4}{*}{1.16} \\
\hline & S. cyanea & - & 02 & 02 & 0.46 & \\
\hline & Z. bettini & - & 01 & 01 & 0.23 & \\
\hline & Sub total & - & 05 & 05 & & \\
\hline \multirow{6}{*}{ Theridiidae } & A. aulicus & 150 & 02 & 152 & 35.27 & \multirow{6}{*}{38.52} \\
\hline & T. simile & 04 & - & 04 & 0.93 & \\
\hline & T. murarium & 03 & - & 03 & 0.70 & \\
\hline & D. nigra & 05 & - & 05 & 1.16 & \\
\hline & P.tepidariorum & 02 & - & 02 & 0.46 & \\
\hline & Sub total & 164 & 02 & 166 & & \\
\hline \multirow{3}{*}{ Thomisidae } & M. vatia & 08 & - & 08 & 1.86 & \multirow{3}{*}{3.25} \\
\hline & T. onustus & 06 & - & 06 & 1.39 & \\
\hline & Sub total & 14 & - & 14 & & \\
\hline Total / Season & & 311 & 120 & 431 & & \\
\hline$\%$ & & 72.16 & 27.84 & & & \\
\hline
\end{tabular}

D.C. $=$ Direct counts $(15$ plants $)$

Pf. T. = Pitfall traps (10)

$\mathrm{M}=31-60$
Categories: $\quad \mathrm{R}=<10$ spiders for season

$\mathrm{L}=11-30$

$\mathrm{H}=>60$

Fayoum J. Agric. Res. \& Dev., Vol. 29, No.2, July, 2015 
Table: (3) Population density and relative abundance of spider families and species collected from tomato fields during (May. 2013 to Sep. 2013) in summer plantation in Fayoum Governorate.

\begin{tabular}{|c|c|c|c|c|c|c|}
\hline \multirow[t]{2}{*}{ Families } & \multirow[t]{2}{*}{ Species } & \multicolumn{2}{|c|}{$\begin{array}{c}\text { Collection } \\
\text { method }\end{array}$} & \multirow[t]{2}{*}{ Season Total } & \multicolumn{2}{|c|}{ Relative abundance\% } \\
\hline & & D. C. & Pf. t. & & (Species) & (Families) \\
\hline \multirow[t]{3}{*}{ Araneidae } & M. wittfeldae & 04 & - & 04 & 0.72 & \multirow{3}{*}{1.44} \\
\hline & Z. $x$-notata & 04 & - & 04 & 0.72 & \\
\hline & Sub total & 08 & - & 08 & & \\
\hline Clubionidae & C. stagnatilis & - & 03 & 03 & 0.54 & 0.54 \\
\hline Dictynidae & D. segregate & 118 & 03 & 121 & 21.88 & 21.88 \\
\hline \multirow[t]{3}{*}{ Gnaphosidae } & D. depressus & - & 03 & 03 & 0.54 & \multirow{2}{*}{0.90} \\
\hline & Z. subterraneus & - & 02 & 02 & 0.36 & \\
\hline & Sub total & - & 05 & 05 & & \\
\hline Linyphiidae & M. fabra & - & 02 & 02 & 0.36 & 0.36 \\
\hline \multirow{8}{*}{ Lycosidae } & A. absoluta & - & 03 & 03 & 0.54 & \multirow{8}{*}{23.14} \\
\hline & L. avida & - & 20 & 20 & 3.62 & \\
\hline & L.carolinensis & - & 65 & 65 & 11.75 & \\
\hline & L. gulosa & - & 07 & 07 & 1.26 & \\
\hline & P. minutes & - & 27 & 27 & 4.88 & \\
\hline & P. piratical & - & 03 & 03 & 0.54 & \\
\hline & P. milvina & - & 03 & 03 & 0.54 & \\
\hline & Sub total & - & 128 & 128 & & \\
\hline Mimetidae & M. puritanus & - & 01 & 01 & 0.18 & 0.18 \\
\hline Miturgidae & C. jovium & 39 & 03 & 42 & 7.59 & 7.59 \\
\hline Philodromidae & T. formicinus & 02 & 33 & 35 & 6.33 & 6.33 \\
\hline Pisauridae & D. triton & - & 02 & 02 & 0.36 & 0.36 \\
\hline \multirow{3}{*}{ Salticidae } & O. lineate & - & 06 & 06 & 1.08 & \multirow[t]{2}{*}{1.44} \\
\hline & Z.bettini & - & 02 & 02 & 0.63 & \\
\hline & Sub total & - & 08 & 08 & & \\
\hline \multirow{4}{*}{ Theridiidae } & A. aulicus & 167 & 04 & 171 & 30.92 & \multirow{4}{*}{34.17} \\
\hline & D. nigra & 11 & - & 11 & 1.99 & \\
\hline & P. epidariorum & 07 & - & 07 & 1.26 & \\
\hline & Sub total & 185 & 04 & 189 & & \\
\hline Thomisidae & M. vatia & 09 & - & 09 & 1.63 & 1.63 \\
\hline Total / Season & & 361 & 192 & 553 & & \\
\hline$\%$ & & 65.28 & 34.72 & & & \\
\hline
\end{tabular}

D.C. $=$ Direct counts (15 plants $)$

Pf. T. $=$ Pitfall traps (10)

$$
\mathrm{M}=31-60
$$

Categories: $\mathrm{R}=<10$ spiders for season

$\mathrm{L}=11-30$

$\mathrm{H}=>60$

Fayoum J. Agric. Res. \& Dev., Vol. 29, No.2, July, 2015 
SURVEY OF SPIDER POPULATIONS (ARANEAE) IN TOMATO

Nili 2013- 2014

As shown in table (4), 28 species in 24 genera in 11 families were found. The largest numbers belong to Theridiidae (159.0 individuals), Lycosidae (88.0 individuals) and Dictynidae (66.0 individuals), represented $35.65 \%, 19.73 \%$ and $14.79 \%$ of the total population, respectively. Miturgids spiders were in moderate numbers 44.0 individuals, represented $(9.86 \%)$. Philodromids, thomisids, araneids and salticids spiders were in low numbers; 24.0, 19.0, 18.0 and 14.0 individuals, represented 5.38\%, 4.26\%, 4.03 and 3.14\%, respectively. Pisaurids, pholcids and linyphiids spiders only represented $1.79 \%, 0.89 \%$ and $0.45 \%$, respectively.

The numbers of $A$. aulicus (Theridiidae) 133.0 individuals and $D$. segregata (Dictynidae) 66.0 individuals these dominant, represented $29.82 \%$ and $14.79 \%$, respectively of the spider populations. The population of the miturgidis $C$. jovium and the lycosidis $P$. montanus were in moderate numbers, represented $9.86 \%$ and $8.07 \%$.

Four species; T. formicines (Philodromidae), L. carolinensis (Lycosidae), $M$. vatia (Thomisidae) and $P$. tepidariorum (Theridiidae) were in low population, represented $5.38 \%, 4.93 \%, 2.91 \%$ and $2.69 \%$ respectively, On the other hand, 20 species were rarely found ( $<10$ individuals/season).

\section{Summer 2014}

Results in table (5) revealed that the existence of 26 species in 22 genera in 12 families. The largest numbers belong to Theridiidae (232.0 individuals), Dictynidae (150.0 individuals) and Lycosidae (136.0 individuals), represented $36.19 \%, 23.40 \%$ and $21.22 \%$, respectively of the total population. miturgids and philodromids spiders were in moderate numbers; (49.0 and 37.0 individuals), represented $7.64 \%$ and $5.77 \%$, respectively. Seven families were rare as follows; Araneidae, Gnaphosidae, Thomisidae, Salticidae, Mimetidae, Pisauridae and Linyphiidae, represented 1.40\%, 1.25\%, 1.25\%, 1.10\%, 0.31\%, $0.31 \%$ and $0.16 \%$ of the populations, respectively.

The numbers of $A$. aulicus (Theridiidae, 207.0 individuals) and $D$. segregata (Dictynidae, 150.0 individuals) were dominant, represented $32.29 \%$, and $23.40 \%$, respectively of the spider populations. Five species namely; $C$. jovium (Miturgidae), L. carolinensis (Lycosidae), P. minutes (Lycosidae), $T$. formicinus (Philodromidae) and L. avida (Lycosidae) were in moderate numbers, represented $7.64 \%, 7.49 \%, 6.08 \%, 5.77 \%$ and $5.46 \%$ of the populations, respectively. One species namely; D. nigra were in low numbers, represented $2.65 \%$. On the other hand, 18 species were rarely found $(<10$ individuals/season).

Fayoum J. Agric. Res. \& Dev., Vol. 29, No.2, July, 2015 
Table: (4) Population density and relative abundance of spider families and species collected from tomato fields during (Nov.2013 to Feb. 2014) in nili plantation in Fayoum Governorate.

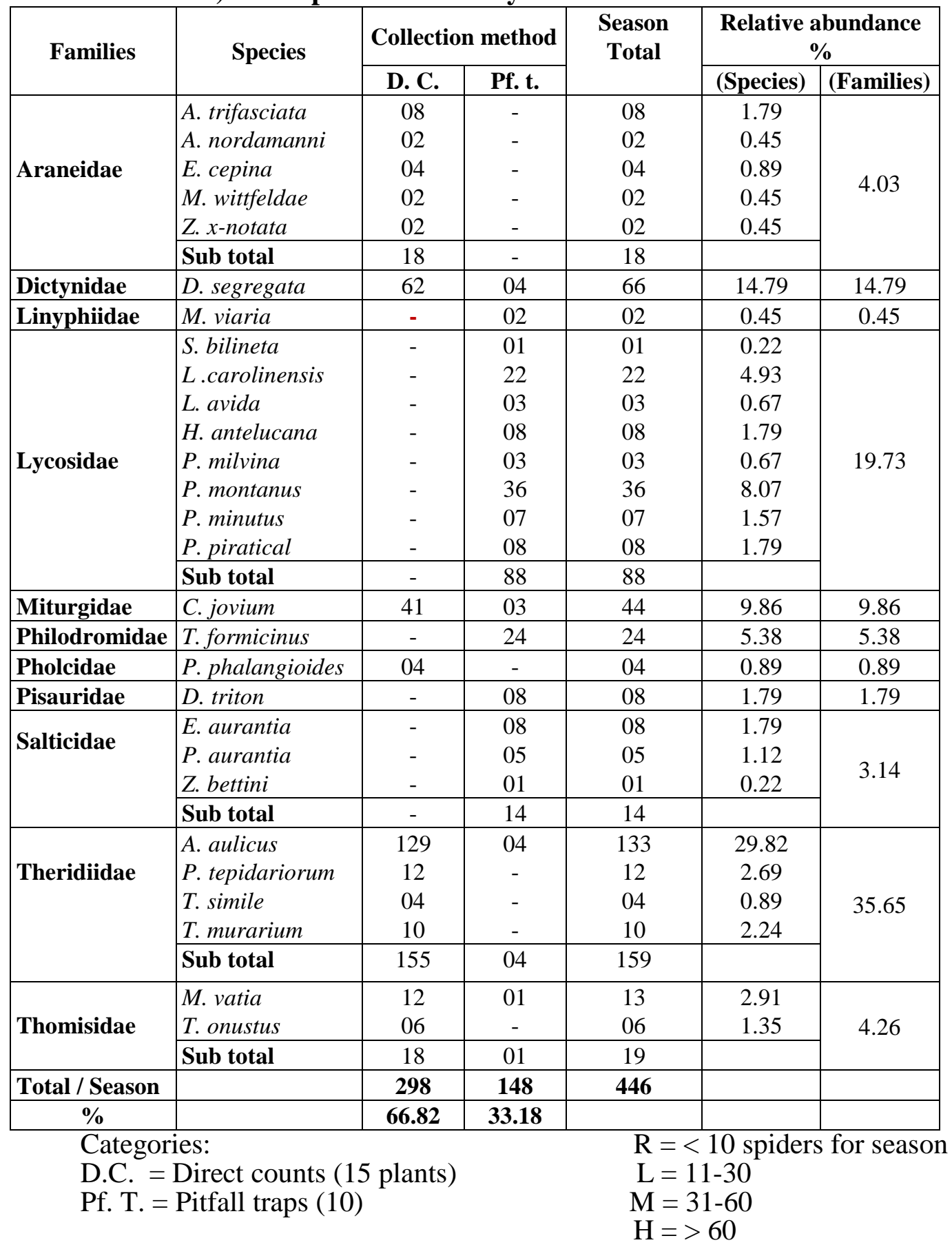

Fayoum J. Agric. Res. \& Dev., Vol. 29, No.2, July, 2015 
SURVEY OF SPIDER POPULATIONS (ARANEAE) IN TOMATO 44

Table: (5) Population density and relative abundance of spider families and species collected from tomato fields during (May 2014 to Sep.2014) in summer plantation in El-Fayoum Governorate.

\begin{tabular}{|c|c|c|c|c|c|c|}
\hline \multirow{2}{*}{ Families } & \multirow{2}{*}{ Species } & \multicolumn{2}{|c|}{ Collection method } & \multirow{2}{*}{$\begin{array}{c}\text { Season } \\
\text { Totals }\end{array}$} & \multicolumn{2}{|c|}{ Relative abundance $\%$} \\
\hline & & D. C. & Pf. t. & & (Species) & (Families) \\
\hline \multirow[t]{3}{*}{ Araneidae } & A. trifasciata & 04 & - & 04 & 0.62 & \multirow{3}{*}{1.40} \\
\hline & M. wittfeldae & 05 & - & 05 & 0.78 & \\
\hline & Sub total & 09 & - & 09 & & \\
\hline Dictynidae & D. segregata & 146 & 04 & 150 & 23.40 & 23.40 \\
\hline \multirow[t]{3}{*}{ Gnaphosidae } & D. depressus & - & 02 & 02 & 0.31 & \multirow{2}{*}{1.25} \\
\hline & Z. subterraneus & - & 06 & 06 & 0.94 & \\
\hline & Sub total & - & 08 & 08 & & \\
\hline Linyphiidae & M. fabra & - & 01 & 01 & 0.16 & 0.16 \\
\hline \multirow[t]{9}{*}{ Lycosidae } & A. absoluta & - & 05 & 05 & 0.78 & \multirow{9}{*}{21.22} \\
\hline & L. avida & - & 35 & 35 & 5.46 & \\
\hline & L. gulosa & - & 02 & 02 & 0.31 & \\
\hline & L. piratical & - & 02 & 02 & 0.31 & \\
\hline & L.carolinensis & - & 48 & 48 & 7.49 & \\
\hline & P. minutes & - & 39 & 39 & 6.08 & \\
\hline & P. milvina & - & 04 & 04 & 0.62 & \\
\hline & S. bilineata & - & 01 & 01 & 0.16 & \\
\hline & Sub total & - & 136 & 136 & & \\
\hline Mimetidae & M. puritanus & - & 02 & 02 & 0.31 & 0.31 \\
\hline Miturgidae & C. jovium & 47 & 02 & 49 & 7.64 & 7.64 \\
\hline Philodromidae & T. formicinus & - & 37 & 37 & 5.77 & 5.77 \\
\hline Pisauridae & P. andulata & - & 02 & 02 & 0.31 & 0.31 \\
\hline \multirow{4}{*}{ Salticidae } & E. aurantia & - & 03 & 03 & 0.47 & \multirow{3}{*}{1.10} \\
\hline & O. lineate & - & 03 & 03 & 0.47 & \\
\hline & Z. bettini & - & 01 & 01 & 0.16 & \\
\hline & Sub total & - & 07 & 07 & & \\
\hline \multirow{4}{*}{ Theridiidae } & A. aulicus & 198 & 09 & 207 & 32.29 & \multirow{4}{*}{36.19} \\
\hline & D. nigra & 17 & - & 17 & 2.65 & \\
\hline & P. tepidariorum & 08 & - & 08 & 1.25 & \\
\hline & Sub total & 223 & 09 & 232 & & \\
\hline \multirow[t]{3}{*}{ Thomisidae } & M. vatia & 03 & - & 03 & 0.47 & \multirow{2}{*}{1.25} \\
\hline & T. onustus & 05 & - & 05 & 0.78 & \\
\hline & Sub total & 08 & - & 08 & & \\
\hline Total / Season & & 433 & 208 & 641 & & \\
\hline$\%$ & & 67.55 & 32.45 & & & \\
\hline \multirow{3}{*}{\multicolumn{4}{|c|}{ Categories }} & \multicolumn{3}{|c|}{$\mathrm{R}=<10$ spiders for season } \\
\hline & & & & \multicolumn{3}{|c|}{$\mathrm{L}=11-30$} \\
\hline & & & & \multicolumn{3}{|c|}{$M=31-60$} \\
\hline
\end{tabular}

Fayoum J. Agric. Res. \& Dev., Vol. 29, No.2, July, 2015 
1.3. Population fluctuations of spider populations in tomato plantations as related to weather conditions in Fayoum.

- Fluctuation in nili season (Nov. 2012 to Feb. 2013):

As shown in fig (1), the density of spiders community in nili plantation 2012-2013, gradually increased from the beginning of plantation till the $1^{\text {st }}$ week of Dec. to record, 24.0, 27.0, 27.0, 29.0, 30.0 and 36.0 individuals, respectively then decreased gradually until the end of population to record 27.0, 25.0, 24.0, 24.0 and 24.0 individuals respectively, from the $2^{\text {nd }}$ week of Dec. till the $4^{\text {th }}$ week of Feb.

Statistical analysis of data indicated that the correlation between the population density and temperature was insignificant positive $(\mathrm{r}=0.291 ; \mathrm{P} \leq$ 0.05:0.242), while the correlation with relative humidity were significant negative $(\mathrm{r}=-0.573 ; \mathrm{P} \leq 0.05$ : 0.013).

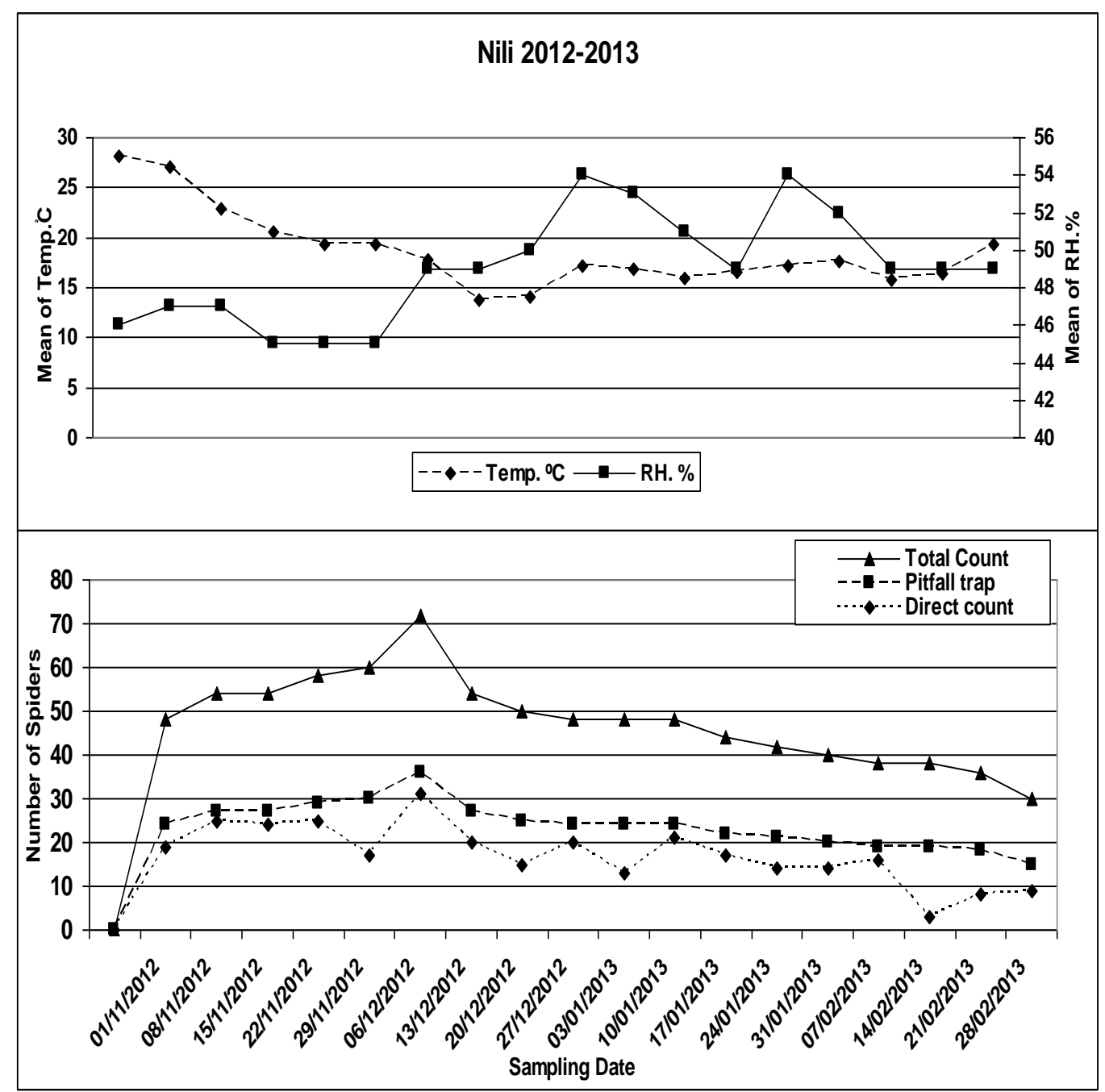

Fig (1) Fluctuation in nili season (Nov. 2012 to Feb. 2013)

Fayoum J. Agric. Res. \& Dev., Vol. 29, No.2, July, 2015 
-Fluctuation in summer season (May to Sep. 2013):

As shown in fig (2), population density of spiders community in summer plantation 2013, gradually increased for three weeks in the beginning of the plantation, to record 19.0 and 22.0 indiv., then decreased for five weeks to record $10.0,11.0,0.16,17.0$ and 20.0 indiv., followed with the highly numbers during plantation with recorded numbers of 22.0, 22.0, 28.0, 32.0, 33.0, 41.0 and 43.0 indiv., respectively. The population decreased sharply for about three weeks to record 22.0, 25.0 and 27.0 indiv., then increased gradually towards the end of the plantation.

Statistical analysis of data indicated that the correlation between the population density and temperature were significant positive $\left(\mathrm{r}=0.458^{*} ; \mathrm{P} \leq\right.$ $0.05: 0.032$ ), also the correlation between the population density and relative humidity were significant positive $\left(\mathrm{r}=0.431^{*} ; \mathrm{P} \leq 0.05: 0.045\right)$.
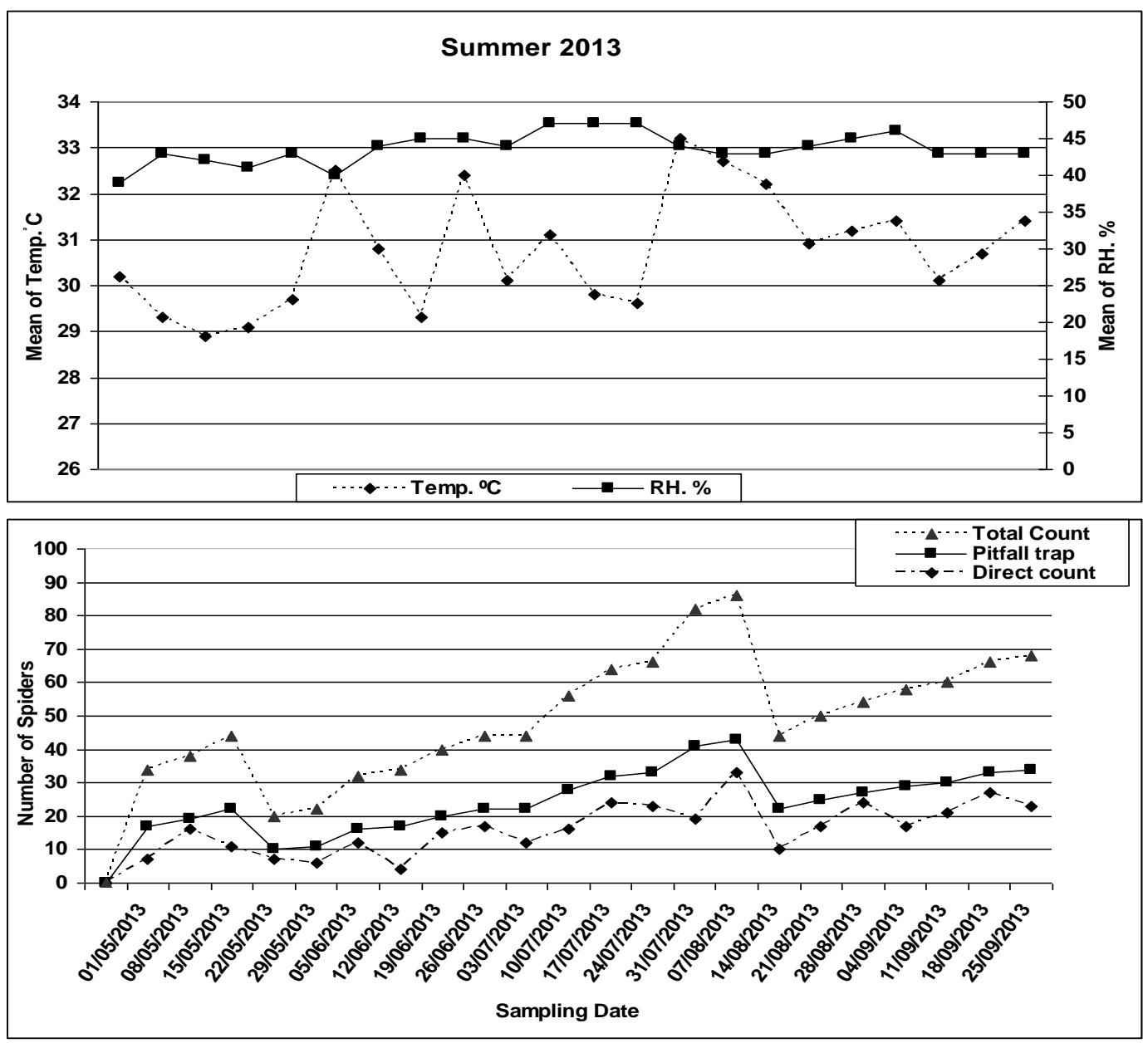

Fig (2) Fluctuation in summer season (May to Sep. 2013)

Fayoum J. Agric. Res. \& Dev., Vol. 29, No.2, July, 2015 
1.3.3. Fluctuation in nili season (Nov. 2013 to Feb. 2014).

As shown in fig. (3), the population density of spider populations, gradually increased from the beginning of plantation to record 28.0, 31.0, 40.0 and 43.0 individuals, respectively during the first four samples and then decreased towards the end of plantation. The least numbers were collected during Feb.

Statistical analysis of data indicated that the correlation between the population density and temperature were significant positive $\left(\mathrm{r}=0.529^{*} ; \mathrm{P} \leq\right.$ 0.05: 0.024), while the correlation between the population density and relative humidity were insignificant negative $(r=-0.444 ; \mathrm{P} \leq 0.05$ : 0.065$)$.

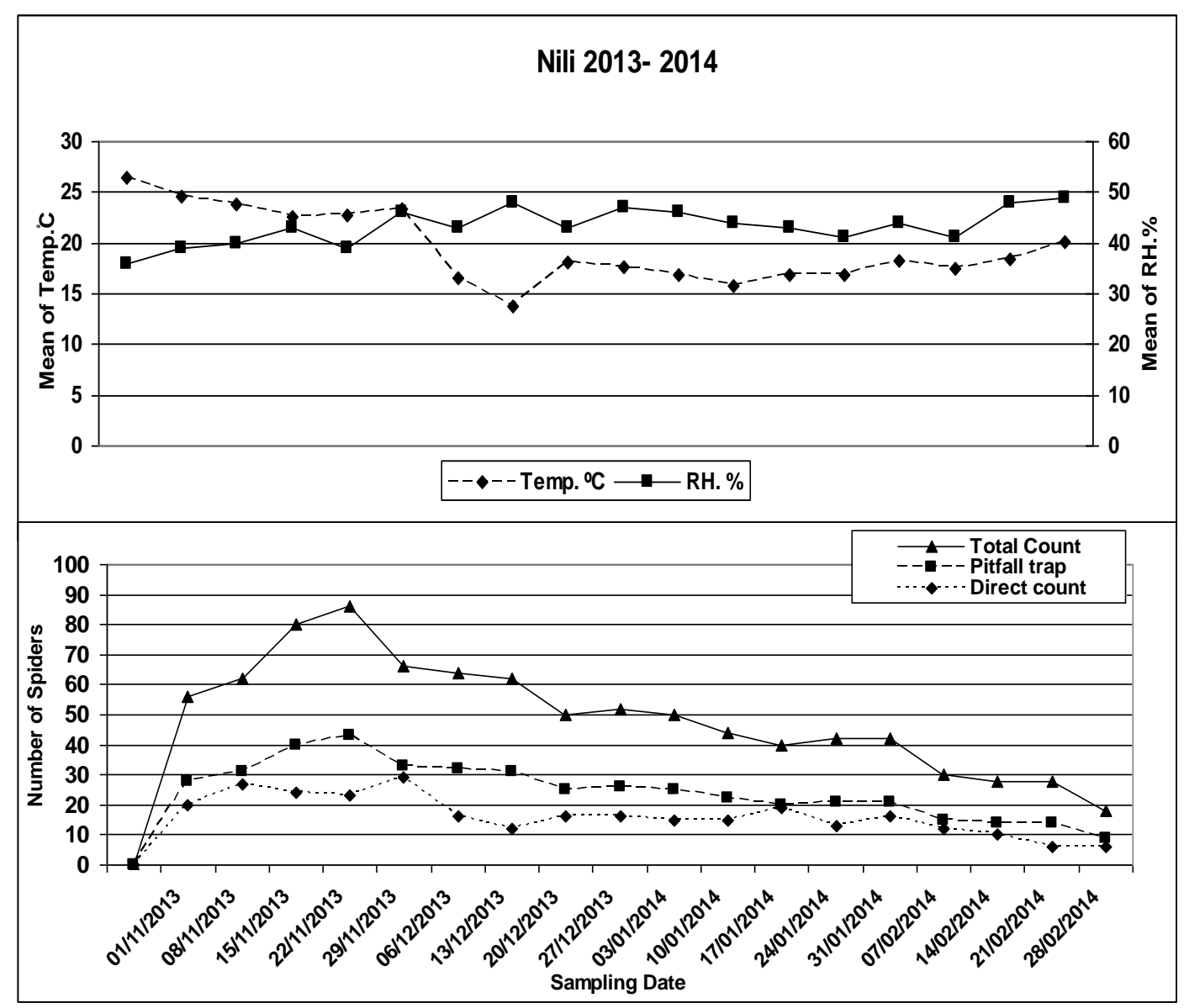

Fig (3) Fluctuation in nili season (Nov. 2013 to Feb. 2014)

Fayoum J. Agric. Res. \& Dev., Vol. 29, No.2, July, 2015 


\subsubsection{Fluctuation in summer season (May to Sep. 2014.)}

As shown in fig. (4), the population density of spider populations in summer plantation 2014, gradually increased from the beginning of plantation and continued throughout the season. The high numbers were collected during July to Aug., while the least numbers were recorded in May and Sep.; On the other hand moderate numbers were collected during June.

Statistical analysis of data indicated that the correlation between the population density and temperature were high significant positive $\left(\mathrm{r}=0.588^{* *} ; \mathrm{P} \leq\right.$ 0.05:0.004), whereas the correlation between the population density and relative humidity were insignificant positive $(\mathrm{r}=0.225 ; \mathrm{P} \leq 0.05: 0.314)$.

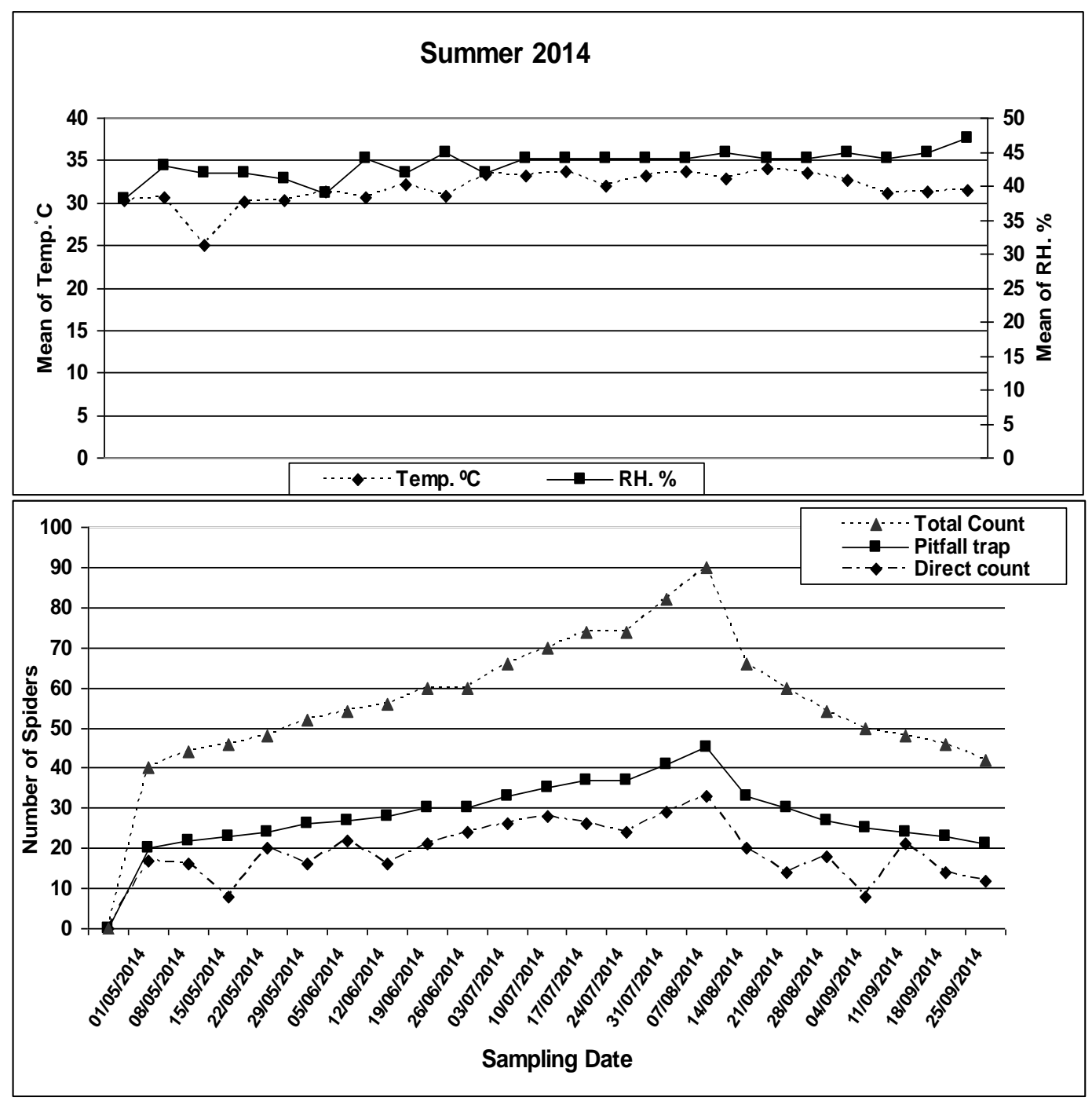

Fig (4) Fluctuation in summer season (May to Sep. 2014)

Fayoum J. Agric. Res. \& Dev., Vol. 29, No.2, July, 2015 
Discussions:

Population density of spiders in tomato fields cultivated at Al-Mandara region, Fayoum Governorate, Egypt during two successive years (2012/20132013/2014), revealed that spiders are found allover the plantation season as indicated by periodic regular collection using two different methods, (direct count and pitfall traps). Population of spiders during two successive years included 42 species in 34 genera in 14 families.

In nili plantation (2012-2013), the numbers of spiders collected (total count) were 431.0 individuals/season; $72.16 \%$ by direct count \& $27.84 \%$ by pitfall traps and in nili plantation, (2013-2014) the numbers were 446.0 individuals/ season; $66.82 \%$ by direct count and $33.18 \%$ by pitfall traps.

In summer plantation (2013), the numbers of collected spiders were 553.0 individuals/ season; $65.28 \%$ by direct count and $34.72 \%$ by pitfall traps. Much more spiders 641.00 individuals/ season were collected during summer plantation (2014) by the above two methods being 433.0 (67.55\%) and 208.0 $(32.45 \%)$, respectively.

In 2012/2013 seasons, a total of 984.0 individuals was collected from tomato plants during nili and summer plantations compared with 1087 individuals in 2013/2014 season (nili and summer plantations).

Rahil, 1988: studied the spider fauna associated with fields of cucurbits (squash-melon) in Fayoum, five families namely; Clubionidae, Linyphiidae, Lycosidae, Theridiidae and Thomisidae were dominant. Spiders of low population densities were those of families; Amaurobiidae and Uloboridae. Spiders found in moderate densities were those of families; Araneidae, Dictynidae, Gnaphosidae and Salticidae.

Ghabbour et al., 1999: surveyed spiders in 18 different agricultural crops in Nile delta in 1996 using pitfall traps. High densities in summer crops were recorded in tomatoes, aborigines and cucurbits and in winter crops observed in caraway, cabbage and onion. Sweet potatoes had the lowest density. In spring, densities varied from 0.4 spiders/trap in taro (Colocasia esculenta) to 6.55 spider/trap in caraway. Ten families were recorded in winter crops compared with 12 in summer. Lycosidae was the dominant in both plantations (80\%), followed by Linyphiidae, Philodromidae, Gnaphosidae and Tetragnathidae. Males were trapped in higher numbers than females.

Rahil, 2006 collected eighteen spider species in six families from tomato fields in El-Fayoum Governorate. These species were; Araneus miniatus (Walckenaer), Eustala anastera (Walckenaer), Mangoraplacida (Hentz), Metazygia wittfeldae (McCook), Singa pratensis Emerton (Araneidae), Dictyna segregate (Gertsch and Mulaik) (Dictynidae), Chieracanthium jovium (Denis) (Miturgidae), Thanatus fabricii Audouin, T. formicinus (Clerck) (Philodromidae), Anelosimus aulicus (Koch), Steatoda triangulosa (Walckenaer), Theridion murarium Emerton, T. tepidariorum (Koch) (Theridiidae), Misumena asperatus (Hentz), M. vatia (Clerck), Misumenops

Fayoum J. Agric. Res. \& Dev., Vol. 29, No.2, July, 2015 
SURVEY OF SPIDER POPULATIONS (ARANEAE) IN TOMATO 50

oblongus (Keyserling), Xysticus elegans Keyserling and X. funestus Keyserling (Thomisidae). Population of these spiders reached up to 25 indiv. $/ 10$ plants at the end of the season (Nov.).

\section{REFERENCES}

Breene, R. G.; Sterling, L.W. and Dean A. D., (1989): Predators of the cotton leafhopper on cotton. South western Entomology. 14: 159-166.

Bristowe, W. S., (1941): The comity of spiders. Vol. LL p. 219-560. Ray Soc., London, $560 \mathrm{pp}$.

Bristowe, W. S., (1958): The world of spiders. (Revised ed.) Collins, London, $304 \mathrm{p}$.

Denis, J., (1947): Results of the Armstrong college expedition to the Siwa oasis (Libyan Desert), 1935. Bull. Soci.Fouad 1er d'Entomologie, 31: 17103.

Ghabbour, S. I.; Hussein A. M and El-Hennawy K. H., (1999): Spider populations associated with different crops in Menoufiya Governorate, Nile Delta, Egypt. J. of Agric. Res., 77 (3) : 11631179.

Kaston, B. and Kaston, E, (1953): How to know the spiders .W.C. Brown Co., Dubuque, Iowa, USA, $220 \mathrm{pp}$.

Levy, G and Amitai, P., (1982): The comb-footed spider genera Theridion, Achaearanea and Anelosimus of Israel (Araneae: Theridiidae). J. Zool. Lond., 196:81-131.

Longino, J. T., (1994): How to measure arthropod diversity in a tropical rainforest. BiologyInternational, 28, 3-13.

Platnick, N. I., (2011): The world spider catalog, version 12.0. American Museum of Natural History, online at http:// research. amnh.org liz/spiders.

Rahil,A.A.R. (1988) .Ecological and biological studies on the spiders at Fayoum, M.Sc. thesis, Fac. Agric., Fayoum, Cairo Univ., 133 pp.

Rahil, A. A. R., (2006): Impact of pesticides used on true spider populations in tomato farms in Fayoum Governorate. Fayoum J. Agric. Res. \& Dev., Vol.20, No1, 148-154.

Sheriff, M. R.; Hendawi S. A and El Habashi, M., (2002): Highlights on the results of national rice research program: Orb weaving spiders. Ibid. 65-69.

Zaki, M., (1992): Production trends for fruit and vegetable crops in Egypt. Ciheam, 147-150.

Fayoum J. Agric. Res. \& Dev., Vol. 29, No.2, July, 2015 


\section{حصر لانواع وتعداد العناكب في حقول الطماطم بمحافظة الفيوم \\ نبيل محمد الخولي، أثرف عبد الحفيظ رحيل وعماد فتحي دويدار

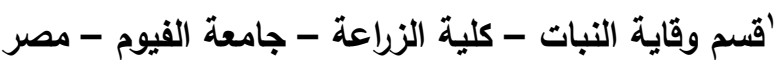

تم عمل حصر كمي ونوعي للعناكب الموجودة علي نباتات الطماطم وذللك في الفترة من نوفمبر

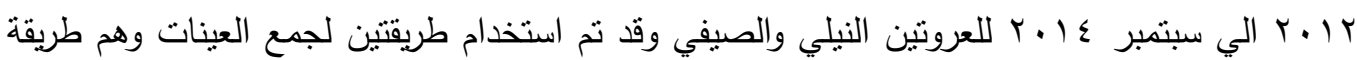
العد المباشر وطريقة المصائد الارضية لمعرفة الكثافة العددية وتذبذب التعداد الموسمي لهذه العناكب. وقد اسفرت النتائج عن الاتي:

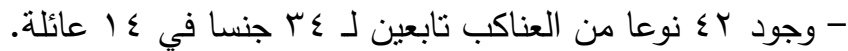

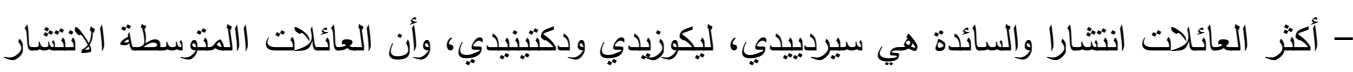
هي العائلتين ميتورجيدي وفيلودروميدي بينما العائلات التي تمثل نسبة منخفضة ونيدة ونادرة هي بالتدريج

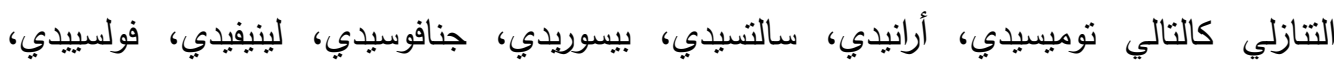

$$
\text { كلوبايوندي ومايميتيدي. }
$$

- الانواع الاكثر انتشارا والتي كانت نمتل نسبة عالية علي مدار الدراسة هي النوع انوليسماس ايوليكاس من عائلة ثريدييدي والنوع ديكتينا سيجريجاتا من عائلة ديكتينيدي.

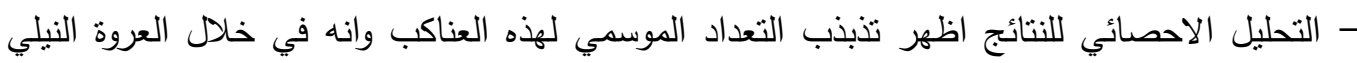

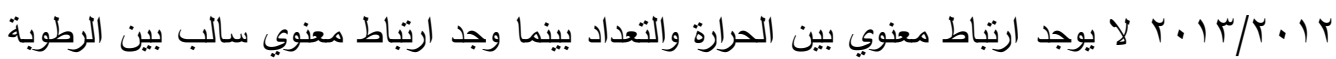

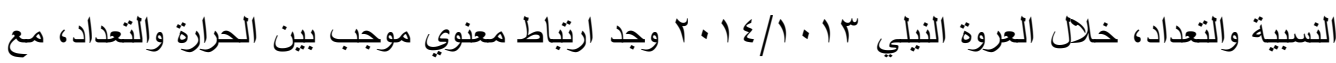

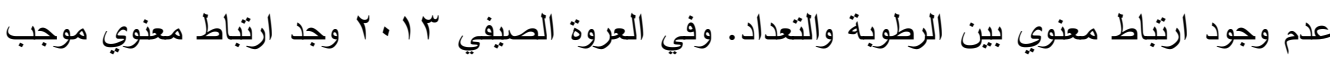
بين الحرارة وكذللك الرطوبة وبين التعداد. ولكن في العروة الصيفي ع ا ـ ب وجد ارتباط معنوي موجب عالي بين الحرارة والتعداد مع عدم وجود ارتباط معنوي بين الرطوبة والتعداد.

Fayoum J. Agric. Res. \& Dev., Vol. 29, No.2, July, 2015 